\title{
$\mathrm{RF}-$ Sputtering 법을 이용한 $\mathrm{ZnO}: \mathrm{Al}$ 박막의 후 열처리에 따른 특성 변화
}

\section{Effects of Post Annealing on the Properties of ZnO:Al Films Deposited by RF-Sputtering}

\author{
이재 형 ${ }^{1, a}$, 이동진 ${ }^{1}$ \\ (Jae-Hyeong Lee, and Dong-Jin Lee')
}

\begin{abstract}
Zinc oxide $(\mathrm{ZnO})$ has been widely studied for its practical applications such as transparent conduction electrodes for flat panel displays and solar cells. Especially, ZnO films show good chemical stability against hydrogen plasma, absence of toxicity, abundance in nature, and then suitable for photovoltaic applications. However, the fabrication process of thin film solar cells require a high substrate temperature and/or post heat treatment. Therefore, the layers have to withstand high temperatures, requiring an excellent stability without degrading their electronic and optical properties. In this paper, we investigated the stability of zinc oxide $(\mathrm{ZnO})$ films doped with aluminum and hydrogen. Doped $\mathrm{ZnO}$ films were prepared by r.f. magnetron sputter and followed by heat treatment at different temperatures and for various times.
\end{abstract}

Key Words : TCO(Transparent conducting oxide), ZnO:Al, RF sputtering, Heat treatment

\section{1. 서 론}

현재 태양전지나 평판 디스플레이 등의 투명전 극과 같이 광전 소자에 사용되어지는 투명전도막 (Transparent conducting oxide, TCO)는 가시광 영역에서 투명하면서 전기 비저항이 낮아 전극물 질의 역할을 하는 막을 말한다. 이 투명전도막은 주로 안정성과 우수한 전기적 특성 때문에 금속 산화물 박막의 한 종류인 ITO(indium tin oxide), $\mathrm{SnO}_{2}, \mathrm{ZnO}$ 계를 주로 사용하고 있으며, 이 가운테 우수한 투과도 $(90 \%, 550 \mathrm{~nm})$ 와 낮은 비저항 $\left(\sim 2 \times 10^{-4}\right)$ 등의 값을 갖는 ITO가 가장 많이 사용 되어지고 있다[1]. 하지만 이리한 우수한 특성을

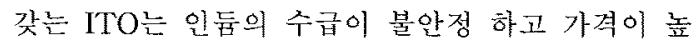

1. 고산대학교 전자정보공학부

(전북 군산시 미룡동 산 68)

a. Corresponding Author : jhyi@kunsan.ac.kr

접수일쟈: 2008. 4. 11

차 심사 : 2008.5 .20

심사완료 : 2008.8 .22
은 뜽의 문제점이 있다. 또한 $\mathrm{ZnO}$ 박막보다 식각 이 어렵고 디스플래이에 적용될시 약 $400{ }^{\circ} \mathrm{C}$ 정도 의 온도와 수소 플라즈마에 노출이 되는데, 일반적 으로 ITO나 금속산화물 박막은 이러한 분위기에서 열화현상 등의 문제점을 가진 것으로 보고되고 있 다[2]. 그러나 $\mathrm{Al}_{2} \mathrm{O}_{3}$ 를 첨가한 $\mathrm{ZnO}: \mathrm{Al}$ 박막의 경 우 ITO 박막 등의 경우에 비헤 비교적 저렴한 원 가와 광학적 특성 및 열적 안정성도 우수한 것으 로 보고되어 현재 $\mathrm{ZnO}$ 에 대한 연구가 활발히 진 행되고 있다[3-5].

대표적인 $\mathrm{ZnO}$ 박막의 증착 방법으로는 스펴터링 법 (Sputtering), 진공 증착법 (Vacuum evaporation), 화학 기상증착법 (CVD)등의 다양한 방법이 있으나 가장 널리 사용되는 방법으로는 스퍼터링 법이 있다.

본 논문에서는 실제 태양전지나 디스플레이의 공정 시 약 $300 \sim 400{ }^{\circ} \mathrm{C}$ 의 온도에서 노출되는데, 이에 따른 얼적 특성 변화를 관찰하기 위하여 스 펴터링 법으로 제조한 $\mathrm{ZnO}: \mathrm{Al}$ 박막을 각각 $300{ }^{\circ} \mathrm{C}$ 와 $400{ }^{\circ} \mathrm{C}$ 에서 시간을 달리하여 열처리 한 후 박 막의 특성 변화를 조사하였다. 


\section{2. 실 험}

본 실험에서 사용된 물질은 $\mathrm{ZnO}$ 에 $2.5 \mathrm{wt} \%$ 의 $\mathrm{Al}_{2} \mathrm{O}_{3}$ 가 합유된 세라믹 타겟(Superconductor Materials Inc., $99.99 \%$ )이 사용되었으며, RF 마그 네트론 스퍼터 장비를 이용하여 $\mathrm{ZnO}: \mathrm{Al}$ 박막을 제 조하였다.

$\mathrm{ZnO}: \mathrm{Al}$ 박막 제조에 사용된 기판으로는 Cornning 7059 Glass를 사용하였고, 박막 중착시 $\mathrm{ZnO}: \mathrm{Al}$ 박 막의 전기적 특성을 향상시키기 위해 도팡 가스로 수소를 아르콘 가스에 $2.5 \%$ 비율로 첨가하여 3.7 $\times 10^{-4} \Omega \cdot \mathrm{cm}$ 의 비저항 값을 갖는 박막을 제작하 였다.

표 1. $\mathrm{ZnO}: \mathrm{Al}$ 박막의 제조 및 열처리 조건.

Table 1. Sputtering and heat treatment conditions for $\mathrm{ZnO}: \mathrm{Al}$ films.

\begin{tabular}{|c|c|}
\hline Deposition parameter & Condition \\
\hline Sputtering power & 170 Watt \\
\hline Working pressure & 2 mTorr \\
\hline Gas ratio & $\mathrm{H}_{2} / \mathrm{Ar}(2.5 \%)$ \\
\hline Substrate temperature & Room temperature \\
\hline Annealing temperature & $300^{\circ} \mathrm{C}, 400{ }^{\circ} \mathrm{C}$ \\
\hline Annealing time & $10 \sim 90 \mathrm{~min}$ \\
\hline
\end{tabular}

한편, 증착이 완료된 $\mathrm{ZnO}: \mathrm{Al}$ 박막은 공기 중에 서 열처리하였는데, 특정 가스 분위기에서보다 순 수 공기 중에서 열처리를 진행하여 열적특성에서 영향을 줄 수 있는 조건들을 최소화 하였다. 또한 열처리시 현재 투명 전도막으로 가장 많이 사용되 고 있는 ITO 박막도 동시에 진행하여 열적 안정성 비교 분석하였다.

표 1 은 $\mathrm{ZnO}: \mathrm{Al}$ 박막의 제조 조건과 열처리 조 건을 나타낸 것이다.

\section{3. 결과 및 검토}

열처리 온도와 시간에 따른 $\mathrm{ZnO} A \mathrm{Al}$ 박막의 구 조적 톡성을 평가하기 위해 XRD 분석과 $\mathrm{SEM}$ 분 석을 하였다.

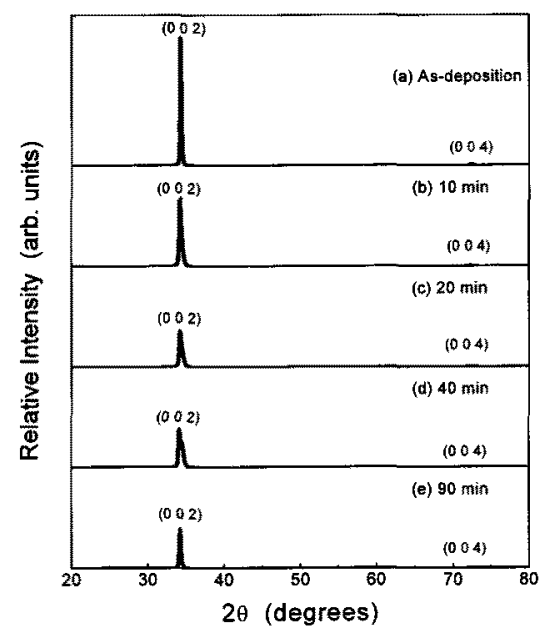

(a) $\mathrm{T}_{\mathrm{a}}: 300{ }^{\circ} \mathrm{C}$

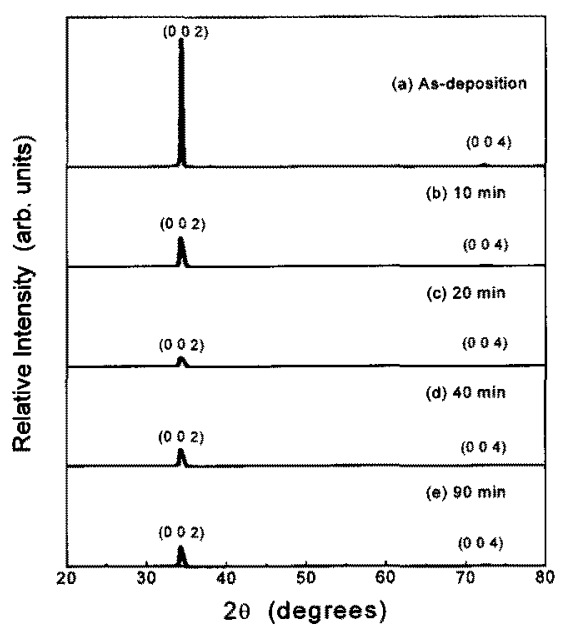

(b) $\mathrm{T}_{\mathrm{a}}: 400{ }^{\circ} \mathrm{C}$

그림 1. 공기 중에서 열처리된 $\mathrm{ZnO} A \mathrm{Al}$ 박막의 열 처리 시간에 따른 $\mathrm{XRD}$ 분석 패턴.

Fig. 1. XRD patterns of $\mathrm{ZnO}: \mathrm{Al}$ films annealed for different times in air.

그림 1은 공기 중에서 각각 $300{ }^{\circ} \mathrm{C}$ 및 $400{ }^{\circ} \mathrm{C}$ 에 서 열처리한 $\mathrm{ZnO}: \mathrm{Al}$ 박막의 열처리 시간에 따른 $\mathrm{XRD}$ 분석 결과를 나타낸 것이다. 먼저 그림 1로 부터 열처리된 $\mathrm{ZnO}: \mathrm{Al}$ 박막은 열처리 온도와 시간 에 관계없이 (002)면의 $\mathrm{c}^{-}$축 방향으로의 우선 배향 성을 지니고 있음을 알 수 있다. 하지만 열처리 시 간이 점점 증가함에 따라 열처리 온도에 관계없이 피크의 세기가 출어드는데, 이는 $\mathrm{ZnO}: \mathrm{Al}$ 박막과 기딴으로 사용된 유리와의 다른 열팽창계수 $(\mathrm{ZnO}$ : 
$5.85 \mathrm{ppm} /{ }^{\circ} \mathrm{C}$, glass: $9.35 \mathrm{ppm} /{ }^{\circ} \mathrm{C}$ )의 차이로 인한 기계적 응력의 영향 때문이라 생각된다. 박막예 가 해지는 응력의 증가는 박막 내부의 결정 격자에 전위 등의 증가를 수반한 결정 변형을 가져올 수 있고, 이는 걸정의 배향성을 감소시킬 수 있는 것 이다[6]. 또한 $400{ }^{\circ} \mathrm{C}$ 에서 열처리된 시편의 피크 세기가 $300{ }^{\circ} \mathrm{C}$ 의 경우보다 작게 나타남을 볼 수 있는뎨, 이것은 $\mathrm{Zn}$ 가 높은 온도로 인하여 휘발하 기 시작하여 결정성이 좋지 않은 결과를 초래한 것으로 $400{ }^{\circ} \mathrm{C}$ 에서 $\mathrm{Zn}$ 이 더 많이 휘발되어 평행한 방향의 압력과 기판에 수직한 방향으로 발생하는 팽창력에 기인한 기계적 응력의 영항 때문이라 사 로된다.

그림 2 와 그림 3 은 공기 분위기의 열처리 조건 에 따른 $\mathrm{ZnO}: \mathrm{Al}$ 박막의 표면 $\mathrm{SEM}$ 분석 결과를 온도별로 구분하여 나타낸 그림이다. 열처리 시간 이 증가함에 따라 입자의 크기가 조금씩 증가하고 있음을 알 수 있다. 하지만 그림 1의 XRD분석에 서도 나타난바와 같이 입자 크기는 증가했더라도 그림 2 와 그림 3 의 $(\mathrm{a})$ 의 열처리를 하지 않은 상태 의 그림과 비교 했을 때 표면이 고르지 못하고 매 우 불규칙적으로 나타난 것을 볼 수 있는데 이것 은 결정이 충분히 촉진되지 못한 결과라 판단된다.

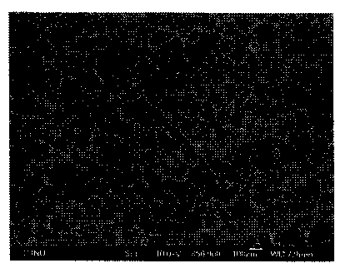

(a) As-deposition

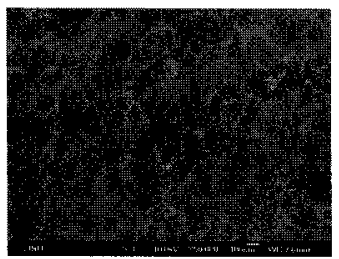

(c) $60 \mathrm{~min}$

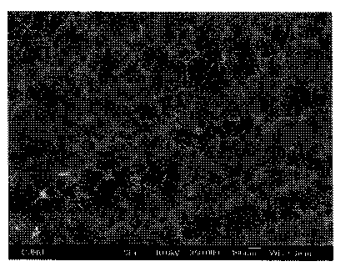

(b) $20 \mathrm{~min}$

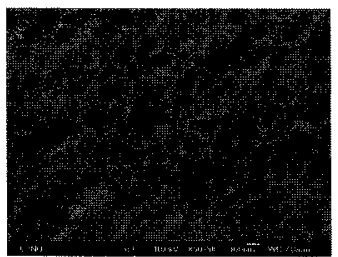

(d) $90 \mathrm{~min}$
그림 2. 공기 중에서 열처리된 $\mathrm{ZnO}: \mathrm{Al}$ 박막의 열 처리 시간에 따른 표면 $\mathrm{SEM}$ 사진 $\left(\mathrm{T}_{\mathrm{a}}\right.$ : $300{ }^{\circ} \mathrm{C}$ ).

Fig. 2. SEM images of $\mathrm{ZnO}: \mathrm{Al}$ films annealed for different times in air $\left(\mathrm{T}_{\mathrm{a}}: 300^{\circ} \mathrm{C}\right)$.

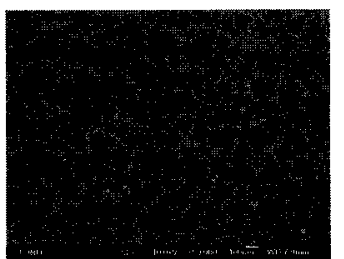

(a) As-deposition

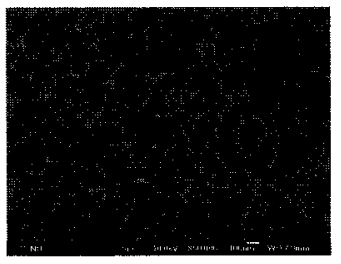

(c) $60 \mathrm{~min}$

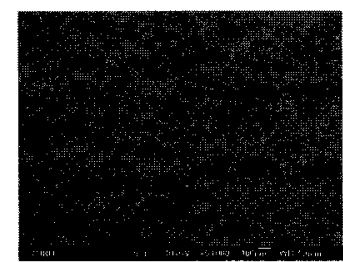

(b) $20 \mathrm{~min}$

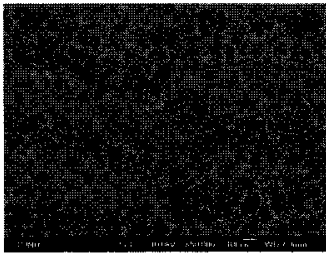

(d) $90 \mathrm{~min}$
그림 3. 공기 중에서 열처리된 $\mathrm{ZnO}: \mathrm{Al}$ 박막의 열 처리 시간에 따른 표면 $\mathrm{SEM}$ 사진 $\left(\mathrm{T}_{a}\right.$ : $400{ }^{\circ} \mathrm{C}$ ).

Fig. 3. SEM images of $\mathrm{ZnO}: \mathrm{Al}$ films annealed for different times in air $\left(\mathrm{T}_{\mathrm{a}}: 400{ }^{\circ} \mathrm{C}\right)$.

그림 4는 공기 중에서 열처리된 ITO 몇 $\mathrm{ZnO}: \mathrm{Al}$ 박막의 열처리 시간에 따른 면저항(sheet resistance) 의 변화를 나타낸 것이다. 이때 열처리 온도는 300 ${ }^{\circ} \mathrm{C}$ 및 $400{ }^{\circ} \mathrm{C}$ 로 고정하여 열처리하였다. 먼저 박막 종류에 관계없이 면저항은 열처리 온도와 시간이 증가함에 따라 커지는 것을 알 수 있다.

$\mathrm{ZnO}: \mathrm{Al}$ 박막의 경우, $300{ }^{\circ} \mathrm{C}$ 의 열처리 온도에서 는 시간에 따라 면저항이 열처리 전의 $3.7 \Omega / s q$.에 서 서서히 증가하여 최대 열처리 시간인 90 분에서 는 $6.4 \Omega / \mathrm{sq}$.의 면저항 값을 나타낸다. $400{ }^{\circ} \mathrm{C}$ 에서 열처리된 시편의 경우 면저항은 $300{ }^{\circ} \mathrm{C}$ 에 비해 열 처리 시간에 따라 크게 증가하였다. 이것은 앞서 살펴본 구조적 분석에서와 일치하는 골과로서 온 도의 상승이 결정성의 저하를 일으켜 $\mathrm{ZnO}: \mathrm{Al}$ 박막 의 전기전도 메커니즘의 중요한 요소인 점 결함 (pointing defect)을 감소시켜 저항이 이처럼 크게 증가한 것으로 생각된다. ITO 박막의 경우도 $\mathrm{ZnO}: \mathrm{Al}$ 박막과 마찬가지로 저항의 증가 변화가 있 있다. 그 중 $300{ }^{\circ} \mathrm{C}$ 의 경우 최고 $12 \mathrm{\Omega} / \mathrm{sq}$. 의 면 저 항률을 보여 오히려 $\mathrm{ZnO}: \mathrm{Al}$ 박막의 전기적 특성보 다 좋지 않았지만 $400{ }^{\circ} \mathrm{C}$ 에서는 $\mathrm{ZnO}: \mathrm{Al}$ 박막보다 약간 적은 증가폭을 보였다.

한편, 그림 4 에서의 열처리 시간에 따른 $\mathrm{ZnO}: \mathrm{Al}$ 


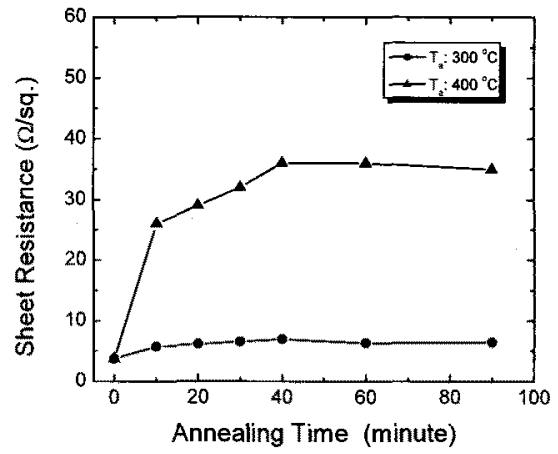

(a) $\mathrm{ZnO}: \mathrm{Al}$ films

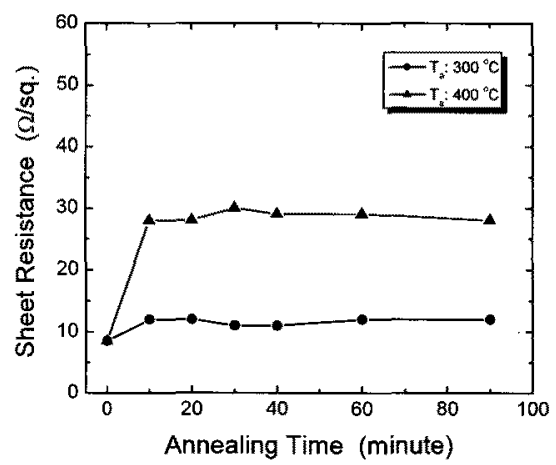

(b) ITO films

그림 4. 공기 중에서 열처리된 ITO 박막 및 $\mathrm{ZnO}: \mathrm{Al}$ 박막의 열처리 시간에 따른 면저 항 변화.

Fig. 4. Dependence of annealing time on the sheet resistance of ITO and $\mathrm{ZnO}: \mathrm{Al}$ films. The samples were annealed at $300{ }^{\circ} \mathrm{C}$ and $400{ }^{\circ} \mathrm{C}$ in air atmosphere.

박막의 면저항의 변화 원인을 조사하기 위해 전기 적 특성 중 캐리어 농도와 홀 이동도를 측정하여 그림 5 에 나타내었다. 보통 $\mathrm{ZnO}$ 의 결정립계에는 음전하를 가진 산소 공공(Oxygen vacancy)들이 위치하여 이들을 결정립계 인근의 고갈층(depletion region)을 형성함으로써 캐리어 농도의 감소와 홀 이동도를 방해하는 원인으로 작용한다. 즉, 이러한 산소 공공(Oxygen vacancy)이 공기 중 분위기의 열처리 공정시 제거가 되지못하여 그림 5 와 같은 졀과가 나타난 것이라 생각된다[1].

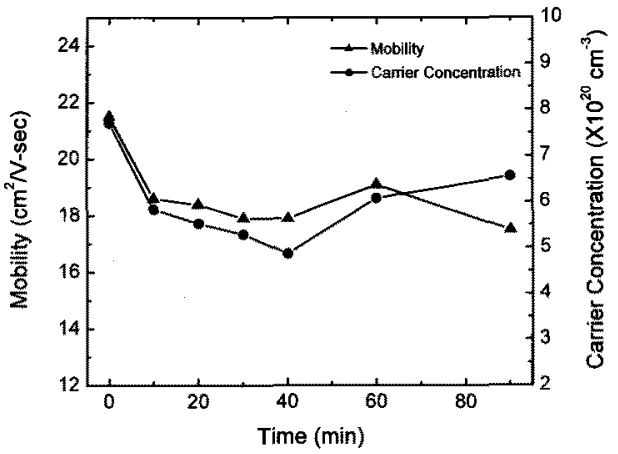

(a) $300{ }^{\circ} \mathrm{C}$

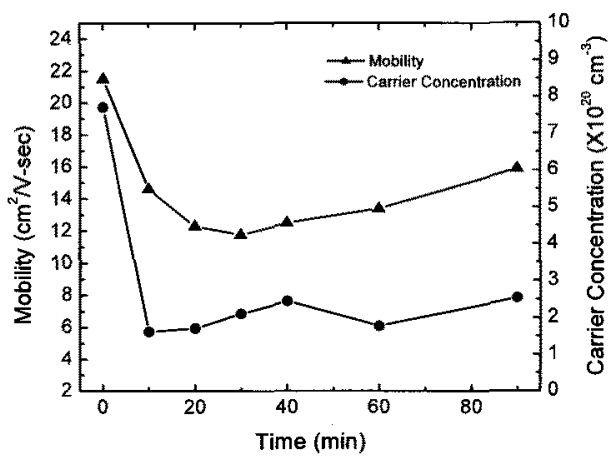

(b) $400{ }^{\circ} \mathrm{C}$

그림 5. 공기 중에서 열처리된 $\mathrm{ZnO}: \mathrm{Al}$ 박막의 열 처리 시간예 따른 캐리어 농도 및 홀 이 동도 변화.

Fig. 5. Hall mobility and carrier concentration of $\mathrm{ZnO}: \mathrm{Al}$ films annealed for different times in air.

그림 6 은 공기 중에서 $300{ }^{\circ} \mathrm{C}$ 및 $400{ }^{\circ} \mathrm{C}$ 의 온도 로 열처리된 $\mathrm{ZnO}: \mathrm{Al}$ 박막의 광투과율을 열처리 시 간에 따라 나타낸 것이고, 그립 7은 $\mathrm{ZnO}: \mathrm{Al}$ 및 ITO 박막의 $400 \sim 700 \mathrm{~nm}$ 범위에서의 정균 광투과 율을 나타낸 것이다. 먼저 $\mathrm{ZnO} \mathrm{Al}$ 박막의 경우 모 든 시편에서 80 85\%의 투과도를 나타내고 있으 며, ITO 박막은 이보다 야ㄱㅏㅏㄴ 높은 약 $90 \%$ 정도 의 광투과율을 보여주고 있다. 투과율의 수치만 보 면 ITO 박막이 $\mathrm{ZnO}: \mathrm{Al}$ 박막보다 높지만, $\mathrm{ZnO}: \mathrm{Al}$ 박막 역시 ITO와 유사하게 열처리 온도나 시간에 관계없이 비교적 늪은 광투과율을 유지하고 있음 


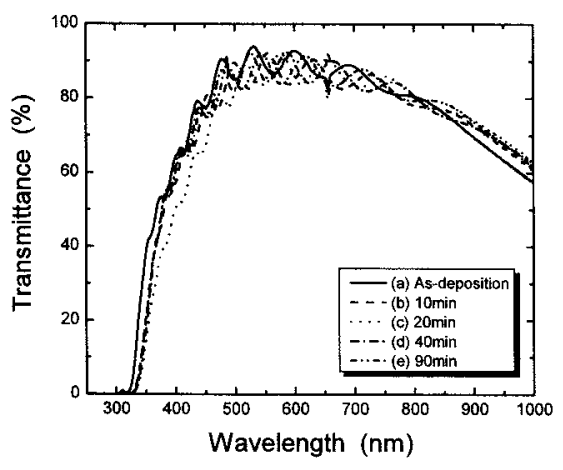

(a) $\mathrm{T}_{\mathbf{a}}: 300^{\circ} \mathrm{C}$

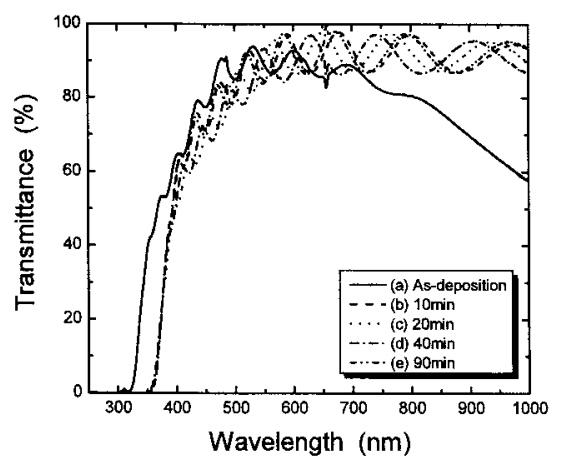

(b) $\mathrm{T}_{\mathrm{a}}: 400{ }^{\circ} \mathrm{C}$

그림 6. 공기 중에서 열처리된 $\mathrm{ZnO}: \mathrm{Al}$ 박막의 열 처리 시간에 따른 광투과율.

Fig. 6. Optical transmittance of $\mathrm{ZnO}: \mathrm{Al}$ films annealed for different times in air.

을 볼 수 있다. $\mathrm{ZnO}: \mathrm{Al}$ 박막의 광투과율은 열처리 분위기를 수소나 산소, 아르곤 등의 가스를 주입하 여 개선을 시킬 수 있다. 한편, 공기 중에서 열처 리된 $\mathrm{ZnO}: \mathrm{Al}$ 박막의 표면 색깔이 열처리 전에 비 해 약간 노란색으로 변하는 것을 육안으로 관찰할 수 있었는데, 이것은 열처리시 공기 중의 산소가 $\mathrm{ZnO}: \mathrm{Al}$ 박막과 화학적인 결합을 통하여 광투과율 을 변화시키기 때문으로 생각된다. 유사한 현상을 ITO 박막에서도 확인할 수 있었다.

일반적으로 상온에서 성장시킨 $\mathrm{ZnO}: \mathrm{Al}$ 및 ITO 와 같은 산화막은 대부분 화학양론적인 조성을 갖 지 못하고 다수의 산소 공공(vacancy)이 존재하게 된다. 이 산소 공공은 $\mathrm{n}$ 형 도편트 역할을 하지만

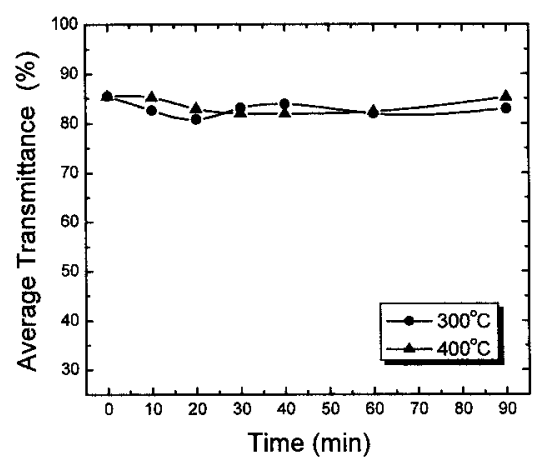

(a) ZnO:Al films

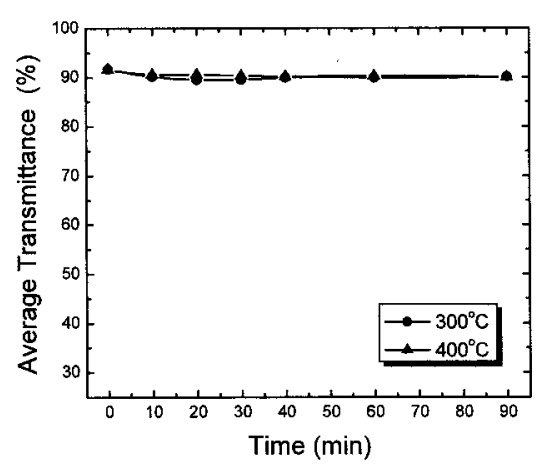

(b) ITO films

그림 7. 공기에서 열리리된 $\mathrm{ZnO}: \mathrm{Al}$ 및 ITO 박막 의 평균 광투과율.

Fig. 7. Average transmittance of $\mathrm{ZnO}: \mathrm{Al}$ and ITO films annealed for different times in air.

광학적 특성으로 볼 때 밴드 갭(band gap)내 불순 물 준위 (impurity level)를 형성함으로 광학적 특성 을 저해하게 된다. 이러한 산소 공공을 줄이기 위해 서는 열처리 분위기에 산소 가스를 주입함으로써 산 화막에 존재하고 있는 산소 공공을 산소로 치환시 켜 공공의 수를 감소시킴으로 개선시킬 수 있으리 라 판단된다.

\section{4. 결 론}

투명 전도막을 태양전지나 디스플례이 둥의 투 
명 전극으로 사용할 때 실제 공정 분위기나 온도 에서의 열적 안정성이 중요하다. 본 연구에서는 기 존의 ITO 박막을 대체할 수 있는 $\mathrm{ZnO}: \mathrm{Al}$ 박막을 박막 태양전지 제작 공정 온도에 해당하는 300 $400{ }^{\circ} \mathrm{C}$ 의 온도에서 열처리하고, 그 톡성 변화를 조 사하였다. 또한 비교률 위해 헌재 투명 전도막으로 가장 많이 사용되고 있는 ITO 박막을 동일한 조건 에서 열처리하였다. 열처리 분위기는 공기 중에서 실시하였다.

열처리된 $\mathrm{ZnO}: \mathrm{Al}$ 박막들의 $\mathrm{XRD}$ 분석 결과 열 처리 온도 및 시간에 관계없이 모두 $(002)$ 방향의 우선 방위를 갖는 것으로 확인되었고, 이 면 방향 으로의 피크 세기는 열처리 시간이 증가함에 따라 점차 감소하였다. 또한 $\mathrm{SEM}$ 분석을 통해 결정립 의 크기가 다소 증가하였지만 결정화가 완전히 촉 진되지 못해 고르지 않고 매우 불규칙적으로 나타 넜다. 이러한 변화는 전기적 특성에게 영향을 미친 것을 알 수 있었다. $300{ }^{\circ} \mathrm{C}$ 의 온도에서 열처리된 $\mathrm{ZnO}: \mathrm{Al}$ 및 ITO 박막의 면저항은 열처리 전에 비 해 다소 증가하였으나 열처리 시간에 따른 큰 변 화는 관찰되지 않았다. 그러나 열처리 온도가 400 ${ }^{\circ} \mathrm{C}$ 인 경우, 물질의 종류에 관계없이 열처리에 의해 면저항이 크게 증가하였다. 열처리 시간에 따른 $\mathrm{ZnO}: \mathrm{Al}$ 및 ITO 박막의 열적 안정성은 $300{ }^{\circ} \mathrm{C}$ 의 열처리 온도에서는 큰 차이가 없었으나, $400{ }^{\circ} \mathrm{C}$ 에 서는 ITO 박막이 비교적 우수한 특성을 나타내었 다. 한편, $\mathrm{ZnO}: \mathrm{Al}$ 박막의 광 투과율은 평균 $80 \%$ 에서 $85 \%$ 의 투과도를 나타내고 있다.

위와 같은 결과들로부터 $\mathrm{ZnO}: \mathrm{Al}$ 박막이 현재 투명 전도막의 재료로 가장 많이 사용되는 ITO를 대체할 수 있는 가능성을 확인할 수 있었다.

\section{감사의 글}

본 연구는 산업자원부 신재생에너지기술개발사 업의 일환 (R-2005-7-147)으로 수행되었습니다.

\section{참고 문헌}

[1] H. L. Hartnagel, A. L. Dawar, A. K. jain, and C. Jagadish, "Semiconducting Transparent Thin Films", Insitute of Physics Publishing, Bristol and Philadelphia, 1995.

[2] T. Minami, H. Sato, H. Nato, and S. Takada, "Heat treatment in Hydrogen gas and plasma for transparent conduction oxide films such as $\mathrm{ZnO}, \mathrm{SnO}_{2}$ and indium tin oxide", Thin Solid Films, Vol. 176, p. 227, 1989.

[3] S. Takata, T. Minami, and H. Nato, "The stablility of aluminium-doped $\mathrm{ZnO}$ transparent electrodes fabricated by sputtering", Thin Solid Films, Vol. 135, p. 184, 1986.

[4] 이동진, 이재형, 주정훈, 이종인, 정학기, 정동 수, 송준태, "Polyimide 기판을 이용한 $\mathrm{ZnO}: \mathrm{Al}$ 박막 특성에 관한 연구", 전기전자재료학회논 문지, 20권, 8호, p. 666, 2007.

[5] 김봉석, 이규일, 강현일, 이태용, 오수영, 이종 환, 송준태, "다층박막을 이용한 Ga-doped $\mathrm{ZnO}$ 투명전도막의 특성", 전기전자재로학회논문지, 20권, 12호, p. 1044, 2007.

[6] F. C. M. VanDe Pol, F. R. Blom, and TH. J. A. Popma, "R.f. planar magnetron sputtered $\mathrm{ZnO}$ films I: Structural properties", Thin Solid Film, Vol. 204, p. 349, 1991. 